\title{
IPTEK Bagi Masyarakat (IbM) Melalui Peningkatan Panen Pedet dan Produksi Kompos Berkualitas Pada Kelompok Ternak Sapi Potong
}

\author{
Bayu Andri Atmoko ${ }^{1 *}$, Endang Baliarti ${ }^{1}$, Nanung Agus Fitriyanto ${ }^{2}$, \\ ${ }^{1}$ Departemen Produksi Ternak, Fakultas Peternakan, Universitas Gadjah Mada, Jl. Fauna No.03, Karang \\ Gayam, Caturtunggal, Depok, Sleman, D.I Yogyakarta 55281, Indonesia. \\ ${ }^{2}$ Departemen Teknologi Hasil Ternak, Fakultas Peternakan Universitas Gadjah Mada, Jl. Fauna No.03, \\ Karang Gayam, Caturtunggal, Depok, Sleman, D.I Yogyakarta 55281, Indonesia. \\ *budisatria@ugm.ac.id
}

Submisi: 12 Maret 2018; Penerimaan: 08 April 2019

Kata kunci: Bull stimulation; jerami fermentasi; panen pedet; pendapatan; pupuk kompos

Keywords: Bull stimulation; fermented straw; calf crop; income; compost
Abstrak Ternak sapi potong merupakan tabungan peternak untuk meneruskan usaha, meskipun secara analisis tidak menguntungkan. Oleh karena itu, diperlukan strategi yang tepat sesuai permasalahan baik budaya peternak msupun sumber daya yang dimiliki. Penelitian dilakukan di kelompok peternak sapi potong penghasil pedet, Mergo Andini Makmur dan kelompok Sumber Ayu, di Kabupaten Sleman. Produktivitas induk sapi kedua kelompok belum baik, S/C lebih dari 2, bahkan sampai 4 kali, post partum estrus lebih dari satu tahun, dan jarak beranak lebih dari 2 tahun. Kelompok ternak sudah melakukan diversifikasi usaha, yaitu pengolahan kotoran sapi, namun belum optimal. Pengabdian masyarakat dilakukan untuk memperbaiki kinerja reproduksi melalui penyediaan pejantan sapi (bull stimulation), penyuluhan, pendampingan pencegahan infeksi cacing, demonstrasi pembuatan pupuk, dan pengolahan pakan. Tahap pertama yaitu persiapan, meliputi konsolidasi dengan pengurus, dilanjutkan dengan sosialisasi program kegiatan. Tahap selanjutnya yaitu pelaksanaan, dengan melakukan penyuluhan manajemen reproduksi/perkawinan, kesehatan ternak, manajemen pakan, dan pengolahan pupuk kompos. Pelaksanaan bull stimulation berjalan selama 1 bulan dengan hasil memuaskan baik dari munculnya birahi (lebih dari 50\%) dan angka perkawinan $(33,33 \%)$ dari populasi induk serta tingkat partisipasi peternak. Demontrasi pembuatan jerami fermentasi dan pupuk kompos juga diimplementasikan sebagai kegiatan pendukung.

Abstract Beef Cattle have a role as saving for farmers to continue their business, although not profitable based on business analysis. Therefore, the right strategy is needed according to the problems of both the culture and the resources of farmers. The community service activity was conducted in a beef cattle farmer groups as cattle breeding for calf production, namely, are Mergo Andini Makmur and Sumber Ayu in Sleman Regency. The beef cattle productivity in the two groups is not good, $S / C$ is more than twice, even up to four times, postpartum estrus is more than one year, and calving interval is more than 2 years. The beef cattle farmer groups have already diversified their business, which is the processing of manure and waste product of cattle, but not yet optimal. Community service is carried out to improve reproductive performance of cattle through the providing of a superior bull for bull stimulation, counseling, assistance in the prevention of worm infections, and demonstrations of compost and feed quality production. The first stage is preparation, including consolidation with the member farmer groups, followed by the socialization of the activity program. The next stage of implementation, by conducting reproductive and breeding management counseling, cattle health management, feed processing and management, and compost production. The result of the implementation of a bull stimulation for one month is based on the emergence of estrus (more than 50\%) following by a conception rate $(33.33 \%)$ of the cows population, and the level of participatory farmers. The demonstration of the fermented straw feed and compost is also implemented as a supporting activity. 


\section{PENDAHULUAN}

Kelompok ternak Village Breeding Center (VBC) merupakan kelompok ternak penghasil sumber bibit Sapi Peranakan Ongole (PO) yang bagus. Penunjukan sebagai VBC sapi potong membawa implikasi bahwa kelompok ternak harus dapat menjadi percontohan bagi kelompok lain, serta mampu menghasilkan bibit Sapi PO sesuai dengan standar bibit bagi yang membutuhkan. Oleh karena itu, Kelompok Ternak "Mergo Andihi Makmur" yang berada di Desa Bolu, Kecamatan Seyegan, dan Kelompok Ternak "Sumber Ayu” yang berada di Desa Brayut, Kabupaten Sleman, Daerah Istimewa Yogyakarta (DIY) yang berjarak sekitar $10 \mathrm{~km}$ dari kampus UGM terpilih sebagai mitra dalam kegiatan dalam kegiatan Iptek bagi Masyarakat (IbM) karena merupakan salah satu kelompok ternak Village Breeding Center (VBC) Sapi Peranakan Ongole (PO) di DIY. Kedua kelompok ternak mitra memelihara sekitar 50 ekor induk sapi potong Peranakan Ongole (PO). Induk sapi ini berasal dari Pemerintah yang diberikan dalam rangka pelestarian dan peningkatan populasi sapi "putih" PO. Oleh karena itu, targetnya adalah panen pedet tinggi sehingga diharapkan dapat menghasilkan Sapi PO kurang lebih 30 sampai 35 ekor setiap tahunnya.

Permasalahan yang dihadapi adalah rendahnya angka panen pedet akibat kinerja induk yang kurang baik. Dilihat dari indikator angka rata-rata service per conception (S/C) hampir mencapai angka 2 disebabkan sebagian besar induk menunjukkan dua kali inseminasi buatan (IB) baru jadi bunting, bahkan ada yang tiga dan empat kali IB. Selain nilai S/C yang tinggi, post partum estrus (PPE) juga panjang, rata-rata 6 bulan, ada yang lebih dari satu tahun, menyebabkan angka panen pedet rendah (Baliarti et al., 2017). Angka panen pedet yang rendah ini mengurangi motivasi peternak dalam memelihara sapi, karena seperti peternak rakyat lainnya, sapi memiliki fungsi sangat penting dalam rumah tangga peternak, yaitu sebagai tabungan yang tidak ternilai 
manfaatnya ketika secara mendadak ada kebutuhan dana. Selain permasalahan kesuburan, dijumpai pula permasalahan tingkat infeksi cacing juga tinggi. Infeksi cacing sangat berbahaya bagi induk sapi, lebih-lebih yang sedang bunting karena dapat menyebabkan kekurangan hemoglobin $(\mathrm{Hb})$. Induk sapi bunting yang menunjukkan kadar $\mathrm{Hb}$ rendah dapat menderita anemis, berakibat terganggunya pertumbuhan dan perkembangan fetus dalam kandungan.

Selain permasalahan angka panen, permasalahan pakan juga belum teratasi. Berdasarkan penelitian mahasiswa (Aji, 2014 dan Ariyanti, 2014) dilaporkan bahwa tingkat konsumsi nutrien pakan belum memenuhi kebutuhan, lebih-lebih untuk sapi bunting tua yang seharusnya mendapat pakan lebih berkualitas. Sebenarnya hasil sisa pertanian banyak dijumpai di kelompok, tetapi belum ada upaya konservasi supaya kandungan nutriennya dapat terjaga, kalau akan disimpan dalam jangka waktu lama. Konsep adanya lumbung pakan sapi milik kelompok ingin diusulkan oleh tim karena kenyataannya kuantitas dan kualitas pakan yang diberikan sangat fluktuatif, tergantung musim dan tingkat kesibukan peternak, mengingat beternak sapi hanya sebagai usaha sambilan.

Permasalahan lain adalah masih belum optimalnya produksi dan kualitas pupuk kompos yang dihasilkan. Kelompok sudah berusaha memproduksi pupuk kompos dengan bahan baku kotoran sapi. Namun, kualitas pupuk yang dihasilkan belum baik. Hasil uji laboratorium menunjukkan kandungan nitrogen pupuk hanya sekitar 1,0 sehingga perlu ditingkatkan. Tampilan bentuk fisik pupuk juga sebenarnya dapat ditingkatkan dengan membuatnya berbentuk granul. Namun mesin pembuat granul belum dimiliki. Seandainya punya, maka selain bentuk kemasan lebih manis, pupuk akan dapat lebih awet dalam jangka panjang karena kadar air lebih terkontrol. 
Berdasarkan kondisi tersebut, sebenanya potensi dan peluang usaha mitra cukup bagus, dengan jumlah induk mencapai 50 ekor. Dalam hal produksi pedet, dari 50 ekor induk sebenarnya mampu menghasilkan 30-35 pedet per tahun. Sumbangan yang luar biasa bagi D.I.Yogyakarta apabila fungsi dan peran kelompok ternak sapi ini dapat optimal karena data menunjukkan jumlah sapi PO saat ini sangat menurun. Selanjutnya, dalam hal produksi pupuk, potensi sebagai produsen pupuk kompos kedua kelompok mitra cukup besar. Dengan populasi induk sapi mencapai 50 ekor, dapat dihasilkan sekitar $750 \mathrm{~kg}$ feses segar/hari atau sekitar $2.250 \mathrm{~kg} / \mathrm{bulan}$. Setelah dicampur dengan sisa pakan dan daun-daunan dapat menghasilkan sekitar 3 sampai 4 ton pupuk kompos/bulan, jumlah yang cukup besar apabila dapat diproduksi dengan kualitas yang bagus. Pada situasi saat ini ketika mulai muncul kesadaran masyarakat untuk menggunakan pupuk kompos karena memahami kalau hanya menggunakan pupuk anorganik kesuburan lahan akan menurun, maka produksi pupuk berasal dari kedua kelompok ini sangat diharapkan dapat berkontribusi meningkatkan produksi pertanian di Kabupaten Sleman pada khususnya. Berdasarkan latar belakang inilah, tim mengusulkan proposal pengabdian masyarakat.

Penerapan IPTEK berdasarkan hasil-hasil riset mengenai produktivitas induk sapi PO di lingkup peternak rakyat ini sesuai dengan prioritas penghiliran riset UGM. Kegiatan ini memiliki beberapa tujuan, yaitu: (1) membentuk kawasan sentra peternakan sapo PO; (2) mengoptimalkan kemampuan pemeliharaan Sapi PO di skala peternak rakyat; (3) meningkatkan panen pedet; (4) meningkatkan status kesehatan induk dari infeksi cacing; (5) meningkatkan efisiensi dan kemandirian penyediaan pakan; dan (6) meningkatakan nilai tambah usaha pertanian-peternakan melalui pengolahan limbah menjadi pupuk kompos. Kegiatan ini sangat bermanfaat bagi kelompok ternak dalam mencapai produktivitas yang optimal dari panen pedet dan 
produk kompos yang secara tidak langsung akan dapat meningkatkan pendapatan anggota. Selain itu, juga diharapkan akan dihasilkan model pemeliharaan sapi di dekat pemukiman padat penduduk yang ramah lingkungan sehingga dapat menjadi percontohan bagi kelompok ternak sapi lainnya di DIY yang jumlahnya ratusan.

\section{PERMASALAHAN}

Permasalahan utama kelompok ternak yang dapat dipetakan dan diinventaris adalah permasalahan kondisi reproduksi induk, yaitu jarak beranak panjang, keberhasilan perkawinan (IB) rendah, tingkat mortalitas pedet tinggi, infeksi cacing, dan pemberian pakan yang rendah nutrisi (kekurangan nutrisi pakan). Selain dari faktor induk Sapi, produksi pupuk kompos dari limbah peternakan belum optimal sehingga belum mampu memberikan nilai tambah.

Sebagai solusi alternatif permasalahan rendahnya angka panen pedet adalah dengan pengadaan pejantan di kawasan kandang kelompok tersebut. Keberadaan pejantan di antara induk sapi terbukti dari beberapa hasil penelitian dapat meningkatkan libido. Secara alamiah, pejantan juga akan setiap saat dapat mendeteksi induk sapi yang sedang berahi karena keterbatasan peternak berada di kandang sangat terbatas. Menurut Pradana (2014) dan Aji (2014), peternak hanya dua kali sehari ke kandang dengan ratarata durasi sekitar 30 menit untuk memberikan pakan dan membersihkan kandang sehingga peternak jarang memperhatikan kondisi berahi sapinya. Padahal estrus pada sapi hanya berlangsung beberapa jam dan sebagian besar justru terjadi pada malam hari. Salah satu faktor rendahnya S/C diduga karena ada berahi yang tidak diketahui pemiliknya.

Keberadaan pejantan juga akan digunakan untuk perkawinan secara alami, mengingat tingginya S/C juga dapat disebabkan waktu pelaksanaan IB kurang tepat. 
Umumnya begitu ada gejala klinis berahi, petugas langsung melakukan IB. Meskipun secara klinis induk menunjukkan estrus, tapi tidak diikuti dengan ovulasi. Tingkat keterampilan petugas IB belum mampu mendeteksi ada tidaknya ovulasi sehingga mungkin di saat inseminator melakukan IB, sebenarnya tidak terjadi ovulasi dan akibatnya tidak terjadi kebuntingan. Berdasarkan latar belakang inilah, tim melaksanakan IbM untuk memperbaiki kinerja reproduksi melalui penyediaan pejantan sapi untuk merangsang berahi induk sapi (biostimulation).

Solusi untuk permasalahan kurang terpenuhinya kebutuhan nutrien dan tidak kontinunya pakan yang diberikan, maka dilakukan demonstrasi cara pengawetan bahan pakan lokal untuk disimpan dengan baik. Dengan membuat lumbung pakan sapi secara gotong royong, diharapkan dapat lebih meningkatkan rasa kebersamaan yang semakin luntur karena tingkat kesibukan masing-masing anggota yang tinggi. Untuk mengatasi infeksi cacing, maka solusinya dengan menggalakkan kebersihan kandang, ternak, dan lingkungan dengan melakukan kerja bakti pada waktu-waktu yang akan ditetapkan kemudian. Untuk permasalahan rendahnya produksi dan kualitas pupuk kompos yang dihasilkan, dilakukan demo pembuatan pupuk kompos sesuai dengan prosedur yang baku.

\section{METODE PENELITIAN}

Kelompok sasaran kegiatan pengabdian adalah peternak yang tergabung di Kelompok ternak Mergo Andhini Makmur (MAM) yang terletak di Desa Bolu, Seyegan, Sleman dan Kelompok Ternak Sumber Ayu (SA) yang terletak di Desa Brayut, Sleman. Kegiatan pengabdian ini dimulai pada bulan April 2017 sampai dengan Oktober 2017. Pelaksanaan kegiatan pengabdian kepada masyarakat ini dilakukan dengan tahapan sebagai berikut: 


\subsection{Persiapan}

Kegiatan diawali dengan sosialisasi rencana kerja Tim dengan ketua kelompok dan perangkat desa, kemudian dilanjutkan dengan fokus grup diskusi dengan semua anggota kelompok peternak sapi pada saat pertemuan rutin kelompok setiap bulan. Pada kesempatan ini secara rinci akan dijelaskan apa saja yang akan dilakukan dan mengatur jadwal kerja supaya setiap peternak dapat berpatisipasi pada setiap kegiatan yang akan dilaksanakan dengan Fishbond diagram (Gambar 1).

Fishbone Diagram

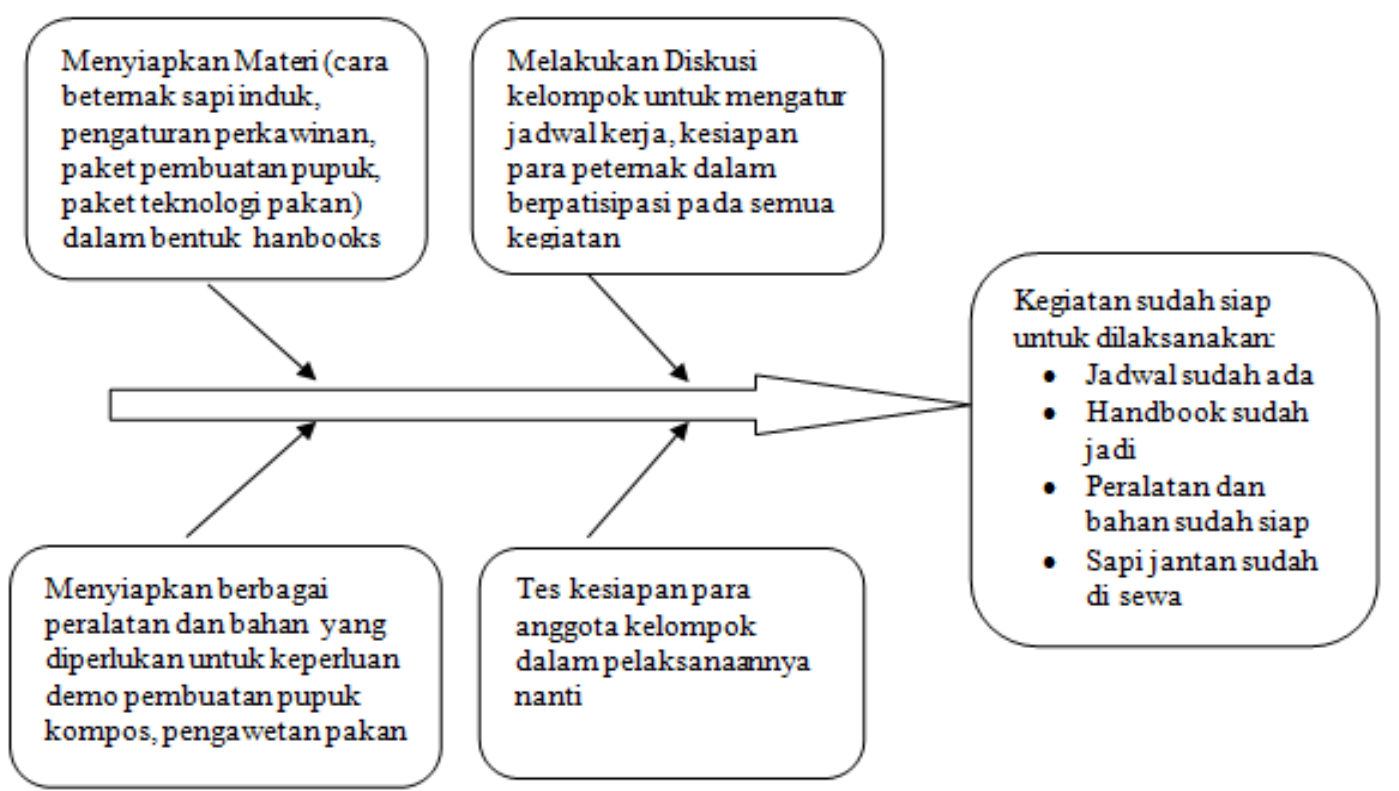

Sumber: Data primer diolah (2017)

Gambar 1. Fishbond diagram kegiatan pada tahap persiapan kegiatan

\subsection{Pelaksanaan}

Pada saat jadwal yang telah disepakati, semua anggota kelompok dikumpulkan dan dibagikan handbook berisi jadwal kegiatan dan materi-materi antara lain, cara pemeliharaan sapi induk, pengaturan perkawinan untuk memperoleh angka panen pedet optimal, paket teknologi pembuatan pupuk kompos, dan paket teknologi pengawetan pakan sapi. Setelah seluruh materi sudah disampaiakan dan dijelaskan kepada peternak, kegiatan selanjutnya adalah dengan melakukan demonstrasi maupun praktik bersama, 
beberapa kegiatan yang disepakati, yaitu: (1) dilakukan demonstrasi pembuatan pupuk kompos; (2) dilakukan demonstrasi pengolahan pakan sapi; (3) selama program berjalan, melakukan pendampingan pada pengaturan perkawinan, pembuatan pupuk kompos, dan pengawetan pakan ternak; dan (4) mengikutsertakan mahasiswa; setiap kali ada kegiatan, mahasiswa dilibatkan. Mahasiswa dibagi dalam kelompok-kelompok, setiap kelompok bertanggung jawab untuk melakukan pendampingan pembuatan paketpaket teknologi sesuai dengan petunjuk dalam handbook.

\subsection{Evaluasi}

Setelah pelaksanaan kegiatan selesai, maka dilakukan tahapan evaluasi. Tahapan evaluasi ini bertujuan untuk mengumpulkan beberapa informasi diantaranya (1) untuk induk sapi, dihitung angka S/C, PPE, jarak beranak, panen pedet yang diperoleh setelah adanya bull stimulation; (2) jumlah pupuk kompos yang telah dibuat, berapa yang laku terjual, berapa uang masuk yang diperoleh selama kegiatan; dan (3) bagaimana hasil pengawetan pakan yang dilakukan dengan melakukan uji laboratorium. Setelah kegiatan IbM selesai, tetap akan dilakukan pendampingan dan monitoring pada kelompok yang dijadikan mitra dengan bantuan mahasiswa.

\section{HASIL DAN PEMBAHASAN}

Kegiatan pengabdian yang sudah dilakukan sampai dengan saat ini antara lain adalah tahap persiapan melalui sosialisasi, dilanjutkan dengan pelaksanaan kegiatan yaitu penyuluhan dan praktik, pendataan peternak dan ternak serta melakukan monitoring dan evaluasi hasil kegiatan. Tim pengabdian secara rutin melakukan pendampingan dan kunjungan lapangan serta diskusi dalam melaksanakan kegiatan. 


\subsection{Tahap Persiapan}

Kegiatan pengabdian diawali dengan melakukan konsolidasi tim pengabdian terlebih dahulu. Setelah itu dilanjutkan dengan membentuk tim pelaksana yang terdiri dari asisten dan mahasiswa pembantu. Setelah tim terbentuk kemudian dilanjutkan dengan pemaparan dan sosialisasi program kegiatan oleh ketua tim. Tim pengabdian kemudian menyusun timeline dan materi yang diperlukan dan disiapkan untuk pelaksanaan antara lain kuisioner untuk peternak, form pendataan peternak dan ternak, modul panduan (handbook) yang praktis dan mudah dipahami oleh peternak.

Tahap selanjutnya adalah dengan melakukan silaturahmi kepada pengurus kelompok ternak dan perangkat desa setempat. Kegiatan ini dilakukan guna memperoleh perizinan. Selain itu, juga disampaikan mengenai rencana dan jadwal kegiatan yang nantinya akan dilakukan bersama antara tim pengabdian dan peternak, baik yang tergabung di kelompok ternak maupun bagi masyarakat desa secara umum. Respons yang diperoleh dari para pengurus kelompok maupun perangkat desa cukup positif dan antusias. Kegiatan ini dirasa sangat sesuai dengan kondisi permasalahan yang selalu dialami oleh para peternak.

\subsection{Sosialisasi}

Kegiatan sosialisasi antara tim pengabdian dan peternak sasaran telah dilakukan Sosialiasi ini bertujuan untuk menyampaikan mengenai rencana, tujuan dan metode kegiatan pengabdian kepada seluruh peternak. Acara sosialisasi dilaksanakan bersama dangan acara rutin pertemuan bulanan kelompok ternak sehingga penyampaiannya dapat optimal pada seluruh anggota. Tim juga memberikan kesempatan bagi para peternak untuk menyampaikan permasalahan yang sedang dan sering menjadi kendala 
selama memelihara induk sapi PO agar hal tersebut dapat dicarikan solusi bersama seiring dengan kegiatan pengabdian.

Hasil yang diperoleh pada tahap kegiatan sosialisasi ini adalah adanya respons yang sangat positif dari seluruh anggota kelompok ternak terhadap rencana kegiatan pengabdian, dan adanya diskusi dua arah atau saling tanya-jawab antara peternak dengan tim pengabdian saat acara sosialisasi program kegiatan pada pertemuan rutin kelompok. Dengan demikian, peternak di masa datang akan termotivasi dan bersemangat untuk mengikuti rangkaian kegiatan pengabdian.

\subsection{Pelaksanaan Kegiatan}

Setelah tahap persiapan dan sosialisasi selesai dilakukan, selanjutnya dilakukan pelaksanaan kegiatan. Pada saat jadwal yang sudah disepakati, semua peternak dikumpulkan dan dibagikan modul panduan (handbook) yang berisi materi-materi kegiatan, antara lain: (a) cara pemeliharaan sapi induk: (b) pengaturan perkawinan; (c) paket teknologi pengolahan pupuk kompos; dan (d) paket teknologi pengolahan pakan sapi.

\subsection{Penyuluhan}

Selanjutnya dilakukan penyuluhan sebagai tindak lanjut dari apa yang sudah disosialisasikan. Tujuan utama kegiatan penyuluhan adalah untuk memberikan wawasan dan pengetahuan serta pembekalan ilmu mengenai pemeliharaan induk sapi PO, pengaturan perkawinan, pengolahan pakan, dan pupuk kompos. Pada kegiatan ini dilakukan penyuluhan menggunakan materi yang sudah disiapkan dan disusun. Kegiatan ini dilaksanakan dengan mengambil waktu sore hari, ketika para peternak dan 
masyarakat desa mempunyai waktu yang cukup karena sudah pulang dan selesai bekerja. Kegiatan ini mendapat respons positif dari peternak.

Materi yang telah disiapkan kemudian disampaikan dan dipaparkan oleh tim pengabdian. Materi penyuluhan yaitu tentang beternak sapi yang meliputi manajemen pemeliharaan, manajemen pakan, manajemen reproduksi, dan perkawinan, perawatan kesehatan, dan pemanfaatan limbah ternak. Dengan metode penyampaian secara sederhana, praktis, dan bahasa yang mudah dipahami maka peserta yang hadir akan mudah mengingat dan memahami materi penyuluhan. Pada kesempatan ini juga banyak disampaikan mengenai permasalahan-permasalahan yang sering muncul dan sedang dihadapi oleh para peternak dalam beternak, yang kemudian ditanggapi dan diberikan solusi oleh tim, sehingga timbul sebuah diskusi dua arah antara tim dan peserta.

Pada kesempatan ini juga dibagikan buku panduan praktis yang sebelumnya sudah disusun dan dipersiapkan oleh tim. Modul panduan ini berfungsi sebagai buku sederhana yang sangat mudah untuk dibaca, dipahami, dan diaplikasikan oleh peternak. Modul panduan dipilih menjadi salah satu media pembelajaran bagi peternak supaya peternak dapat belajar secara mandiri setelah mengikuti kegiatan penyuluhan. Selain itu, diharapkan bagi masyarakat umum yang belum mempunyai ternak sapi akan muncul motivasi dan minat untuk memulai beternak setelah mengikuti penyuluhan dan memperoleh modul panduan. Setelah penyuluhan selesai, dilanjutkan dengan praktik dan demonstrasi kegiatan. Beberapa praktik kegiatan yang sudah dilakukan adalah sebagai berikut.

\subsection{Pendataan Peternak dan Ternak}

Pendataan dan pencatatan merupakan hal utama yang harus dilakukan untuk menerapakan Good Breeding Practice (GBP) oleh peternak. Selain itu, juga menjadi 
salah satu upaya untuk mengoptimalkan fungsi kelompok ternak dalam mengorganisasi dan mengontrol kegiatan beternaknya. Dengan adanya kegiatan ini, ternak akan lebih mudah dikontrol diamati produktivitasnya.

Pendataan dilakukan dengan menggunakan kuisioner. Pendataan profil peternak, latar belakang peternak, dan manajemen pemeliharaan ternak yang dilakukan dapat dijadikan landasan dasar untuk pengembangan dan peningkatan sumber daya manusianya. Pendataan ternak bermafaat sebagai catatan riwayat dan produktivitas ternak tersebut, yang nantinya akan dibuatkan kartu identitas ternak pada masingmasing ternak dan peternak. Hasil pendataan peternak diperoleh jumlah aggota kelompok ternak MAM sebanyak 26 orang mempunyai ternak, populasi ternak sapi yaitu 84 ekor, yaitu pupulasi induk 49 ekor (13 sedang dalam kondisi bunting) dan 35 ekor pedet baik jantan maupun betina. Semua ternak sapi dipelihara di kandang kelompok. Berdasarkan hasil pendataan, diperoleh 27 ekor induk sapi yang akan diberi perlakuan rangsangan berahi dengan menggunakan pejantan (bull stimulation).

\subsection{Pelaksanaan Bull Stimulation}

Bull stimulation secara umum dapat berperan untuk: (1) merangsang munculnya berahi, (2) mendeteksi adanya berahi pada induk yang mengalami gangguan berahi tenang (silent heat), dan (3) mengawini induk yang berahi secara alami sehingga tingkat keberhasilan perkawinan tinggi. Cara ini dirasa paling tepat diaplikasikan di kelompok mitra untuk mengatasi permasalahan rendahnya kinerja reproduksi induk seperti panjangnya PPE, adanya berahi tenang, dan rendahnya keberhasilan perkawinan (S/C tinggi).

Setelah dilakukan pendataan kemudian disusun layout rute pelaksanaan dan penerapan bull stimulation mulai tanggal 30 Juli 2017 selama 1 bulan. Pelaksanaan 
dilakukan oleh asisten dan mahasiswa pembantu yang mencapai 10 orang yang tergabung dalam tim pelaksana setiap hari, yaitu pada pagi pukul 08.00 sampai dengan pukul 10.00 dan sore hari pukul 16.00 sampai dengan pukul 17.30. Sapi pejantan yang terpilih berdasarkan kriteria, antara lain sehat, tubuh proporsional, lincah dan agresif, umur di atas 2 tahun, mampu mengawini dan libido tinggi yang kemudian disewa oleh tim selama dua bulan.

Sapi pejantan dibawa atau dituntun oleh asisten/mahasiswa mengelilingi kandang sesuai dengan rute yang sudah ditentukan dalam layout. Saat berada di depan kandang tambatan, sapi didekatkan dengan induk selama beberapa menit. Sapi induk diamati perubahan tingkah lakunya apakah menujukan tanda-tanda berahi. Apabila menunjukan tanda-tanda berahi sapi kemudian akan dilaporkan peternak pemilik untuk meminta izin dikawinkan. Peternak bebas memilih untuk dikawinkan dengan IB atau secara alami dengan pejantan. Setiap kejadian berahi dicatat di logbook. Sapi yang tidak berahi akan dilanjurkan pada sore ataupun esok hari kembali.

Penilaian kategori berahi berdasarkan scoring tanda-tanda berahi sapi, antara lain seperti kejadian dan tingkah laku induk pada saat didekati pejantan yang dituntun oleh mahasiswa, yaitu mengendus, keluar lendir bening kental dari vulva, perubahan warna pada vulva, berusaha menaiki sapi lainnya, induk gelisah, mengeluarkan suara terus-menerus (bengak-bengok). Selain itu, juga dilakukan penilaian terhadap tingkah laku pejantan pada saat mendekati induk, antara lain mengeluarkan preputium dan penis (ereksi), mencoba menaiki induk yang didekati, menjilat-jilat induk, flehmen (mencengirkan hidung dan bibir bagain atas). Masing-masing tanda /tingkah laku berahi yang muncul akan mendapat skor satu (1) dan nol (0) jika tidak menunjukkan tanda/tingkah laku berahi. Sapi dikategorikan berahi apabila mencapai skor enam sampai sepuluh. 


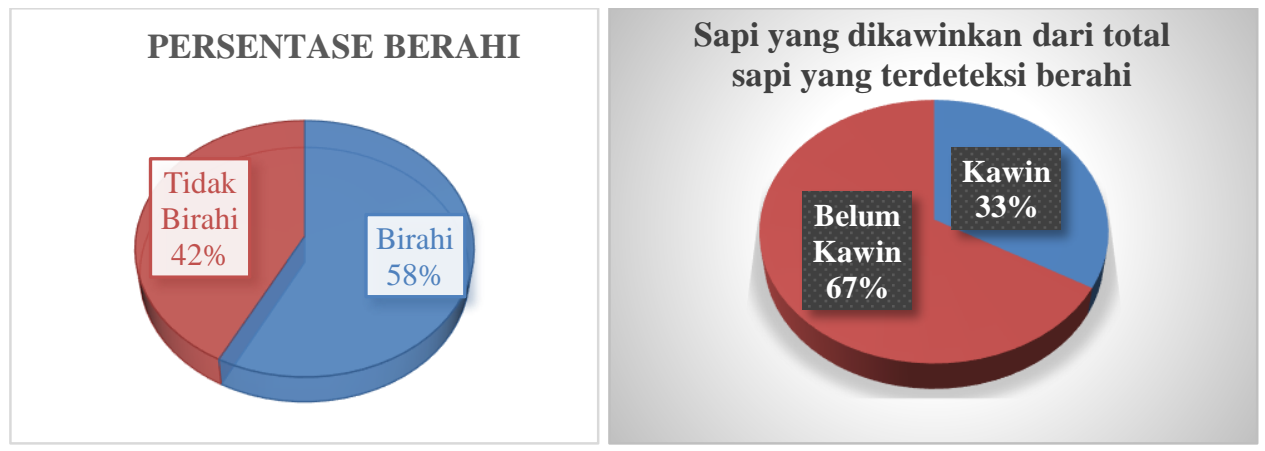

Sumber: Data primer diolah (2017)

Gambar 2. Grafik persentase pencapaian berahi dan sapi yang dikawinkan hasil pelaksanaan bull stimulation

Kegiatan ini berlangsung selama satu bulan. Berdasarkan catatan, induk yang menunjukan ketegori berahi berdasarkan scoring mencapai 15 ekor, yang artinya sudah mencapai $50 \%$ dari total induk yang ada di kandang kelompok. Sedangkan jumlah induk yang sudah dikawinkan adalah 5 ekor dari 15 ekor induk yang dikategorikan berahi (Gambar 2).

Biostimulation adalah istilah yang diciptakan untuk menggambarkan pengaruh stimulasi pejantan pada berahi dan ovulasi melalui organ reproduksi atau stimulasi feromon (Rekwot et al., 2001). Sekarang diketahui bahwa komunikasi pheromonal berperan penting dalam perilaku mamalia dan proses reproduksi. Komunikasi kimia dengan feromon merupakan salah satu cara mentransmisikan informasi tersebut. Pada mamalia, pensinyalan dan priming feromon diperkirakan bertindak baik secara tunggal atau kombinasi melalui stimulasi penciuman, pendengaran, dan visual (penglihatan). Feromon adalah zat kimia yang terbawa udara ("sinyal") yang dilepaskan di urin atau kotoran hewan atau dikeluarkan kelenjar kulit yang dirasakan oleh sistem penciuman dan menimbulkan respon perilaku dan endokrin pada kelompok konsekuen (Rekwot et al., 2001).

Pada sapi, biostimulasi salah satunya dapat dipicu oleh sapi jantan (Burns and Spitzer, 1992). Paparan sapi jantan pada induk menurunkan interval post partum 
anestrus atau mempercepat PPE (Berardinelli \& Joshi, 2005; Landaeta-Hernández et al., 2006; Miller \& Ungerfeld, 2008). Rata-rata interval dari beranak dengan dimulainya kembali aktivitas ovarium untuk sapi MBE (mature bull exposure) atau dengan keberadaan pejantan adalah 71,7 hari, yang secara signifikan terjadi setelah beranak daripada sapi NBE (mature bull exposure) atau tanpa keberadaan pejantan dengan durasi 77,8 hari. Sapi MBE lebih banyak mencapai PPE pada 60 sampai 80 hari pasca beranak daripada sapi NBE (Rekwot et al., 2001). Hasil penelitian (LandaetaHernández et al., 2006), terhadap induk Sapi Angus pasca beranak menunjukan bahwa kelompok yang disediakan pejantan di dalam pen menghasilkan gejala/tingkah laku berahi yang lebih tinggi dibandingkan dengan kelompok yang tidak tersedia pejantan, dibuktikan pada PPE pertama maupun pada PPE kedua, persentase gejala/tingkah laku berahi induk sapi pada kelompok dengan pejantan dibandingkan dengan kelompok tanpa pejantan adalah $98,3 \%$ vs $75 \%$ dan $86,7 \%$ vs $12,5 \%$.

Selain untuk mempercepat PPE, biostimulasi dengan pejantan pada betina muda dapat mempercepat awal pubertas. Paparan sapi potong pra-pubertas umur 12 bulan selama 35 hari mempercepat timbulnya pubertas (Fiol et al., 2010). Biostimulasi jantan pada betina periode pra-pubertas menghasilkan pengurangan yang signifikan pada umur kebuntingan pertama pada Sapi Nelore yang dipelihara pada sistem manajemen ekstensif di lingkungan tropi (Oliveira et al., 2009). Hal ini menunjukan bahwa dengan adanya kedekatan fisik antara pejantan dan betina muda secara positif memengaruhi respons, dan berat badan awal betina muda pada saat pencapaian pubertas.

Dalam hal biostimulasi ini, faktor pakan diminimalisasi karena keseragaman jenis pakan yang diberikan peternak, yaitu jerami padi dan jarang diberi pakan suplemen/konsentrat. Kaitanya dengan faktor pakan pada biostimulasi, (Oliveira et al., 2009), melaporkan bahwa efek positif dari biostimulasi pada pematangan seksual 
(sexual maturity) Sapi Nelore muda lebih tinggi dibandingkan dengan faktor pakan. peran pakan dalam hasil tersebut dapat dianggap sebagai faktor tambahan yang terlibat dalam masa pubertas. Faktor biostimulasi sangat jelas, terutama karena tingkat kebuntingan Sapi Nelore dengan adanya biostimulasi (kelompok BIO dan BIO + S) lebih besar daripada hewan non-biostimulasi, bahkan bagi mereka yang mendapat suplementasi gizi $(\mathrm{NBIO}+\mathrm{S})$.

Keberhasilan merangsang dan mendeteksi berahi kegiatan ini mendapat respons yang sangat baik oleh peternak, peternak sangat antusias menunggu tim melakukan biostimulation baik di pagi hari maupun di sore hari. Dari hari ke hari partisipasi peternak mengalami peningkatan terhadap kegiatan ini. Setelah memberikan pakan dan membersihkan kandang, peternak sudah standby di kandang masing-masing menunggu giliran induk sapinya dirangsang berahi dengan pejantan. Di lain sisi, pada kegiatan ini peternak juga banyak belajar mengenai deteksi berahi dengan mengenali tanda-tanda tingkah laku sapi induknya sehingga dapat menyerap dan meningkatkan pengetahuan dan kemampuan (softskill) dalam memelihara ternaknya. Hal tersebut tentu menjadi salah satu capaian dari target kegiatan pengabdian ini, yaitu menimbulkan motivasi partisipasi aktif peternak serta tingkat kepuasan peternak saat sapinya dapat mengalami berahi sehingga segera dapat dikawinkan dan diharapkan akan berdampak terhadap peningkatan panen pedet peternak pada kelompok ternak tersebut.

Selain itu, kegiatan ini juga menghasilkan kerjasama dengan Loka Penelitian (Lolit) sapi potong lokal (di bawah koordinasi Badan Penelitian dan Pengembangan Pertanian, Kementerian Pertanian Republik Indonesia) berupa penyediaan/peminjaman pejantan Sapi PO berkualitas sejumlah 3 ekor untuk didistribusikan ke kelompok ternak dalam rangka program bull stimulation. Lolit Grati memberikan bantuan berupa pejantan Peranakan Ongole (PO) unggul untuk memperbaiki kinerja induk sapi yang 
ada di kelompok ternak mitra baik MAM dan SA. Cara ini dilakukan sebagai upaya pengembangan networking dan hilirisasi pengembangan hasil-hasil riset yang sudah dilakukan kedua instansi. Sapi pejantan yang berasal dari Lolit Grati merupakan sapi terbaik yang sudah teruji sebagai pemacek. Sapi-sapi tersebut nantinya akan diadaptasi terlebih dahulu di kandang laboratorium selama dua minggu sebelum didistribusikan ke kelompok.

\subsection{Pengamatan infeksi cacing}

Kegiatan ini dilakukan dengan cara melakukan pengecekan pada kondisi feses induk sapi yang dipelihara di kandang kelompok. Sampling feses induk sapi (sejumlah 30\% dari populasi induk) dan uji laboratorium dilakukan untuk mengetahui jenis dan jumlah infeksi telur cacing. Sampling feses dilakukan dengan mengambil/mencuplik feses dari dalam rektum sapi, kemudian dimasukkan ke dalam wadah pastasol, dan diencerkan dengan larutan formalin $20 \mathrm{ml}$. Sampel kemudian diuji secara laboratorium parasitologi di Fakultas Kedokteran Hewan UGM. Berdasarkan hasil uji laboratorium tersebut akan dilakukan penyuluhan mengenai langkah-langkah pencegahan dan penanggulangan infeksi cacing pada sapi maupun pengobatan cacing secara serentak di kelompok ternak. Namun, apabila tidak ditemukan kasus infeksi cacing yang menghawatirkan dan berbahaya maka hanya akan dilakukan sosialisasi terhadap hasil sampling dan uji laboratorium tersebut.

Selanjutnya pengenalan cacing dilakukan dengan memberikan informasi terkait dengan nama cacing, karakteristik, ciri-ciri, dan sifatnya. Kemudian dijelaskan juga mengenai bahaya dari cacing tersebut, tanda-tanda sapi yang terkena cacingan, cara penanganan dan pencegahan cacingan, serta yang utama adalah pengobatan sapi yang terkena cacingan. Kebersihan kandang dan pemberian pakan yang cukup serta pemberian obat cacing yang teratur merupakan upaya utama dari pencegahan cacingan. 
Upaya tersebut secara umum sudah dijalankan oleh peternak di kedua kelompok mitra, kandang rutin dibersihkan setiap dua kali sehari pada pagi dan sore hari, pemberian pakan sudah baik serta pemberian obat cacing yang teratur.

\subsection{Pembuatan Pakan Fermentasi}

Jerami padi merupakan produk samping pertanian yang tersedia melimpah dan relatif mudah diperoleh dibanding produk pertanian lainnya. Ketersediaan jerami padi dalam jumlah yang cukup melimpah ini merupakan peluang besar untuk dimanfaatkan sebagai pakan dan sumber energi bagi ternak ruminansia. Namun, pemanfaatan jerami padi sebagai pakan memiliki faktor pembatas, yaitu tingginya serat kasar dan rendahnya kandungan nitrogen. Nilai kecernaan bahan kering jerami padi hanya mencapai 35 sampai $37 \%$ dan kandungan protein kasarnya hanya sekitar 3 sampai 4\%, padahal temak ruminansia membutuhkan bahan hijauan pakan dengan nilai kecernaan minimal 50 sampai 55\% dan kandungan protein kasar sekitar 8\% (Thalib et al., 2000). Oleh karena itu, kualitas jerami padi perlu ditingkatkan agar pemanfaatannya sebagai pakan dapat menjadi lebih baik. Salah satu pendekatan adalah dengan perlakuan fermentasi.

Kegiatan pembuatan jerami padi fermentasi dilakukan untuk menindaklanjuti kegiatan penyuluhan yang sudah dilakukan sebelumnya. Kegiatan pembuatan jerami padi fermentasi dilakukan bersama dengan peternak di lingkungan kandang kelompok. Kegiatan ini diawali dengan persiapan dan sosialisasi serta dropping bahan pakan dan peralatan untuk membuat jerami fermentasi. Pelaksanaan kegiatan pembuatan jerami fermentasi dilakukan dengan diskusi terlebih dahulu mengenai definisi jerami fermentasi, manfaat jerami fermentasi, bahan tambahan yang dibutuhkan, dan cara membuat jerami fermentasi tersebut. Diskusi berlangsung dengan baik dan lancar. 
Pembuatan pakan fermentasi pernah dilakukan di kedua kelompok ternak mitra, tetapi karena kurangnya pemahaman peternak terhadap manfaat pembuatan dan penggunaan pakan fermentasi menyebabkan peternak berhenti membuat pakan fermentasi. Peternak merasa pembuatan pakan fermentasi hanya membuang waktu dikarenakan lamanya proses pembuatan pakan hingga pemanenannya sehingga peternak lebih memilih untuk memberikan jerami secara langsung tanpa difermentasi. Padahal untuk memenuhi kebutuhan indukan sapi bunting diperlukan pakan dengan kandungan nutrisi yang tinggi. Pakan fermentasi yang dibuat diharapkan dapat meningkatkan kandungan nutrisinya.

Bahan pakan yang digunakan dalam pembuatan jerami padi fermentasi antara lain jerami padi yang sudah disediakan oleh peternak, EM 4 sebagai mikrobia starter, molasses sebagai energi untuk mikrobia, urea untuk meningkatkan PK, dan air sebagai pelarut. Jerami padi tersebut mudah diperoleh dan dijumpai di area sekitar kandang. Selama ini pemanfaatan jerami padi masih belum optimal, peternak hanya memberikan jerami padi secara langsung. Padahal kandungan nutrien jerami padi hanya sekitar 5\%. Oleh karena itu, diperlukan usaha untuk meningkatkan nilai nutrien maupun kecernaannya, salah satunya melalui kegiatan fermentasi (Tabel 1).

Campuran jerami dibuat kemudian dimasukkan ke dalam plastik kedap udara untuk menghindari masuknya udara. Proses fermentasi berlangsung selama 21 hari. Seluruh kegiatan ini dilakukan langsung oleh mahasiswa dan peternak. Setelah selesai difermentasi, dibuka dan diangin-anginkan serta dilakukan kontrol kualitas meliputi aroma, warna, tekstur, dan ada tidaknya jamur. Setelah itu dilakukan pemberian kepada ternak sapi secara adaptasi. Pemberian jerami fermentasi dilakukan secara sedikit demi sedikit hingga sapi dapat mengkonsumsinya dengan baik. Respons sapi terhadap pakan 
sudah cukup baik ditandai dengan dikonsumsinya jerami padi fermentasi yang diberikan.

\section{Talbel 1. Proporsi Bahan Pakan dalam Pembuatan Jerami Padi Fermentasi}

\begin{tabular}{ll}
\hline Bahan pakan & Proporsi (\%) \\
\hline Jerami padi & $99,9 \%$ \\
Urea & $0,006 \%$ \\
Molasses & $0,006 \%$ \\
Starter & $0,006 \%$ \\
Air & secukupnya \\
\hline
\end{tabular}

\section{Sumber: Data primer diolah (2017)}

\subsection{Pengukuran Produksi Feses}

Kegiatan pengukuran produksi feses terkait dengan pelaksanaan program pembuatan pupuk kompos atau organik yang berkualitas sehingga dapat menmberkan nilai tambah bagi peternak dari usaha peternakan sapinya. Kegiatan ini bertujuan untuk mengetahui produksi feses sapi induk per hari per ekor, dan nantinya akan digunakan untuk mengestimasi produksi feses keseluruhan populasi sapi di kandang kelompok sebagai bahan baku pupuk kompos yang akan dibuat. Selain itu juga akan dilakukan pengamatan kondisi feses segar terkait dengan kadar airnya. Apabila kadar air belum memenuhi standar bahan baku kompos yang ditetapkan maka akan dilakukan perlakukan pejemuran maupun pengeringan untuk menurunkan kadar air sesuai dengan standar.

Produksi feses dihitung dengan cara mengukur jumlah feses yang dikeluarkan dalam waktu 24 jam, dan dilakukan selama 3 hari pengukuran yaitu pada tanggaal 10 sampai dengan 12 Agustus 2017. Pengukuran produksi feses dilakukan pada 17 ekor sapi PO dengan status fisiologis yang berbeda, tujuannya adalah untuk mengetahui tingkat produksi feses pada masing-masing sapi dengan status fisiologis yang berbeda sehingga dapat diestimasi jumlah produksi feses per hari sapi yang dipelihara oleh 
anggota kelompok ternak tersebut. Diperoleh hasil rata-rata produksi feses per hari pada pedet/anak sapi adalah 7,05 kg, pada sapi dara (betina muda) adalah $14,02 \mathrm{~kg}$, pada sapi induk kosong (tidak sedang bunting) adalah $14,13 \mathrm{~kg}$, dan pada induk sedang bunting adalah 19,24 kg (Gambar 3).

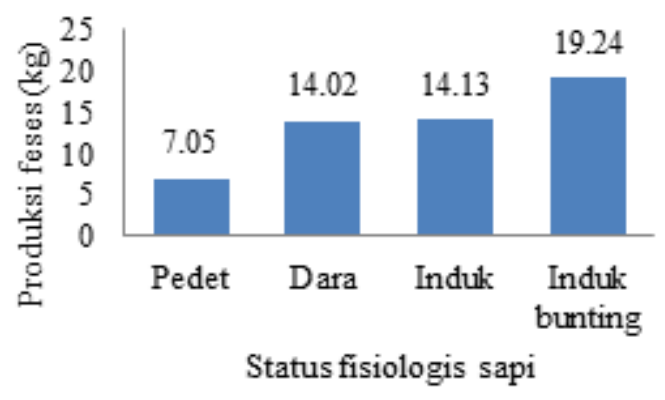

Sumber: Data primer diolah (2017)

Gambar 3. Grafik produksi feses sapi pada status fisiologis yang berbeda di Kelompok Ternak Mergo Andhini Makmur

Berdasarkan produksi feses tersebut, maka dapat diprediksi jumlah produksi feses di kelompok ternak MAM dan SA. Dengan jumlah populasi 26 ekor induk di SA, maka dalam satu hari dapat dihasilkan $364 \mathrm{~kg}$ feses segar. Sedangkan di MAM dapat dihasilkan sejumlah $835 \mathrm{~kg}$ feses segar. Hasil pengukuran produksi feses tersebut menandakan bahwa potensi feses untuk diolah menjadi pupuk organik sangat baik, dan kontuinitas ketersediaanya terjamin, sehingga dapat dimanfaatkan sebagai nilai tambah dari memelihara sapi.

Selain pengukuran produksi feses, juga dilakukan analisis laboratorium pupuk kompos yang sudah dibuat kelompok ternak MAM sebelum kegiatan pengabdian (Tabel 2). Berdasarkan hasil tersebut maka dapat diketahui bahwa pupuk kompos yang sudah dibuat perlu untuk ditingkatkan kualitasnya dengan berbagai bahan starter tambahan serta metode yang lebih efektif dan efisien sehingga hasil pengolahan pupuk kompos dapat optimal. Demonstrasi kegiatan pembuatan pupuk kompos berkualitas dilakukan pada tahap selanjutnya. 
Tabel 2. Hasil Analisis Laboratorium Sampel Pupuk Kompos yang Dibuat Peternak di Kelompok Ternak Mergo Andhini Makmur

\begin{tabular}{|c|c|c|c|c|c|c|}
\hline \multirow{2}{*}{ No } & \multicolumn{6}{|c|}{ Kadar hasil analisis } \\
\hline & Air $(\%)$ & $\mathrm{Abu}(\%)$ & C organik (\%) & $\mathrm{N}$ total $(\%)$ & $\mathrm{P}(\mathrm{ppm})$ & $\mathrm{K}(\mathrm{ppm})$ \\
\hline 1 & 51,78 & 29,24 & 6,02 & 1,38 & 4286,59 & 13366,1 \\
\hline 2 & 51,78 & 29,51 & 5,75 & 1,67 & 4570,83 & 13366,1 \\
\hline
\end{tabular}

Berdasarkan hasil uji laboratorium, kandungan pupuk organik yang telah dibuat sudah cukup baik. Kualitas pupuk organik ditentukan oleh kandungan unsur-unsur hara tanaman yang ada di dalamnya. Kandungan unsur karbon $(\mathrm{C})$, nitrogen $(\mathrm{N}), \mathrm{P}_{2} \mathrm{O}_{5}, \mathrm{~K}_{2} \mathrm{O}$, dan unsur mineral makro lainnya dapat dianalisis di laboratorium. Hal tersebut dapat dinilai dari kadar $\mathrm{C}, \mathrm{N}$, dan $\mathrm{C} / \mathrm{N}$ rasio, angka tersebut diperoleh karena proses dekomposisi yang belum terjadi secara optimal sehingga unsur karbon masih cukup tersedia dalam jumlah yang banyak.

\subsection{Pembuatan Pupuk Organik}

Pembuatan pupuk organik sebenarnya sudah pernah dilakukan di kelompok ternak mitra, namun karena kurangnya kesadaran peternak dan informasi pemasaran pupuk organik yang dihasilkan maka pembuatan pupuk organik tidak dilanjutkan. Padahal kelompok ternak tersebut sudah memiliki tempat dan peralatan yang mendukung dalam pembuatan pupuk organik. Pembuatan pupuk organik dilakukan oleh mahasiswa dan para peternak secara bersama-sama. Pembuatan pupuk organik sangat baik untuk diterapkan karena di sekitar lokasi peternakan merupakan lahan pertanian yang sangat luas dan subur sehingga kaitanya dengan peternakan sapi adalah sebagai sumber pupuk organik lahan pertanian. Dengan adanya perbaikan manajemen budidaya sapi dan pengolahan limbah maka akan terjadi suatu model pengembangan peternakan terpadu 
dengan pertanian. Teknologi pengolahan limbah ternak yang dilakukan adalah untuk meningkatkan pendapatan dari usaha peternakan sapi.

Pelatihan pembuatan pupuk organik yang dilakukan di kelompok ini bertujuan untuk meningkatkan kesadaran anggota kelompok untuk tetap memproduksi pupuk organik. Komposisi bahan pupuk organik yang dibuat di kelompok ternak Sumber Ayu disajikan pada Tabel 3. Proses pembuatan kompos dilakukan dengan pencampuran semua bahan yang kemudian diperam selama 1 bulan. Pembalikan kompos dilakukan setiap 1 minggu sekali. Setelah 1 bulan, kompos diangin-anginkan supaya mengurangi kadar air sehingga nantinya dapat diamati warna, tekstur dan ada tidaknya jamur. Selanjutnya kompos yang sudah jadi disaring menggunakan ayakan. Hasil dari ayakan siap untuk dikemas.

Tabel 3. Proporsi Bahan Pembuatan Pupuk Organik di Kelompok Ternak Mergo Andhini Makmur

\begin{tabular}{ll}
\hline Bahan & Persentase $(\%)$ \\
\hline Feses sapi & 90 \\
Jerami padi & 5 \\
Abu & 0.5 \\
Kapur pertanian & 4 \\
EM4/ starter & 0.05 \\
Molasses & 0.05 \\
Air & 0.4 \\
\hline
\end{tabular}

Sumber: Data primer diolah (2017)

\subsection{Pengawasan dan evaluasi}

Monitoring dan evaluasi dilakukan dengan melihat dan mengukur indikator kinerja dan capaian dari kegiatan pengabdian ini apakah sudah dapat mencapai target dan luaran yang diinginkan. Pengukuran indikator keberhasilan rangkaian program kegiatan dilakukan dengan melakukan pendataan melalui kuisioner pada peternak dan mengukur hasil perbaikan kinerja induk. 
Indikator capaian target berupa partisipasi aktif peternak dalam setiap kegiatan pengabdian yang dilaksanakan tampak dari respons positif, kemauan untuk mengikuti setiap kegaiatan, serta sifat gotong-royong yang sudah ditunjukan selama kegiatan berlangsung sampai dengan saat ini. Indikator capaian target adopsi sistem perkawinan oleh kelompok ternak dan peningkatan kinerja induk yang dipelihara dapat diamati dan dinilai dari munculnya berahi. Kinerja reproduksi induk dengan mengukur indikator lainnya seperti angka S/C, PPE, jarak beranak dan panen pedet yang diperoleh. Evaluasi kegiatan pengabdian juga dilakukan dengan melakukan wawancara terhadap beberapa peternak pada saat kegiatan pengabdian berakhir. Hasil tersebut disajikan pada Tabel 4, dan peternak merasakan manfaat dari kegiatan pengabdian tersebut. Manfaat yang diperoleh berdasarkan informasi langsung dari peternak adalah dapat membuat pakan yang baik, mudah, dan murah. Peternak dapat mengetahui jenis-jenis pakan sapi, mendapat ilmu pengetahuan baru untuk memelihara sapi, dan dapat membuat pupuk organik dari limbah ternak sapi.

Selain itu juga menghasilkan kerjasama dengan Loka Penelitian (Lolit) Sapi Potong Lokal (Badan Penelitian dan Pengembangan Pertanian, Kementerian Pertanian Republik Indonesia) berupa penyediaan/peminjaman bantuan pejantan Sapi PO berkualitas sejumlah 3 ekor untuk didistribusikan ke kelompok ternak dalam rangka peningkatan angka panen pedet dan kinerja reproduksi induk melalui program bull stimulation. 


\section{Tabel 4. Hasil Evaluasi Kegiatan Pengabdian}

\begin{tabular}{clll}
\hline No & \multicolumn{1}{c}{ Pertanyaan } & Ya & Tidak \\
\hline 1 & $\begin{array}{l}\text { Program pengabdian yang dilakukan sesuai dengan kebutuhan } \\
\text { anggota kelompok ternak }\end{array}$ & $100 \%$ & $0 \%$ \\
2 & $\begin{array}{l}\text { Materi pengabdian yang disampaikan sudah sesuai dengan yang } \\
\text { diharapkan }\end{array}$ & $100 \%$ & $0 \%$ \\
3 & $\begin{array}{l}\text { Metode penyampaian materi pengabdian dan pelatihan sudah } \\
\text { sesuai dengan yang diharapkan }\end{array}$ & $83 \%$ & $17 \%$ \\
4 & $\begin{array}{l}\text { Manfaat yang diperoleh dari kegiatan pengabdian } \\
5\end{array}$ & $100 \%$ & $0 \%$ \\
Mengaplikasikan materi pelatihan yang telah diberikan & $83 \%$ & $17 \%$ \\
\hline umber: & Data primer diolah (2017) &
\end{tabular}

\section{KESIMPULAN}

Pengabdian mendapatkan respons yang sangat posistif dari peternak anggota kelompok ternak baik di Kelompok Mergo Andhini Makmur maupun di Sumber Ayu. Peternak berpartisipasi aktif dalam setiap kegiatan yang sudah dilaksanakan. Minat peternak dalam peningkatan kinerja induk melalui pejantan sangat tinggi. Pembuatan jerami fermentasi dan pupuk kompos sudah dilakukan bersama-sam dengan peternak dan tim. Selain itu juga telah dilakukan kerja sama dengan Lolit Grati. Perlu pendampingan secara terus-menerus pada kedua kelompok ternak tersebut agar kegiatan pengabdian dapat berjalan dengan baik dan mencapai target yang diinginkan.

Teknologi pengolahan pupuk kompos masih perlu ditingkatkan kuantitas dan kualitasnya berdasarkan hasil pengukuran kualitas secara laboratorium. Belum dapat diukur kinerjanya seperti pupuk kompos yang telah dibuat, berapa yang laku terjual, berapa uang masuk yang diperoleh selama kegiatan, begitu juga dengan tingkat infeksi cacing dan teknologi pengolahan pakan belum dapat diukur tingkat konsumsi pakan dan kandungan nutrisi pakan awetan. Namun demikian untuk program pembuatan pakan jerami fermentasi dan pupuk kompok dari feses ternak mendapat respons dan partisipasi dari peternak. Pakan jerami fermentasi dan pupuk kompos sudah diproduksi secara bersama-sama dengan asisten mahasiswa dan peternak, diharapkan peternak akan 
termotivasi untuk terus melanjutkan kegiatan pembuatan kompos dan pakan jerami fermentasi tersebut agar dapat mengefisienkan dalam penggunaan bahan pakan dan menambah nilai ekonomis dari limbah dari usaha peternakan sapi menjadi pupuk kompos berkualitas baik.

\section{DAFTAR PUSTAKA}

Aji, R. S. (2014). "Pengaruh Umur Induk Sapi Peranakan Onggole Terhadap Service Per Conception di Kelompok Ternak di Kecamatan Seyegan, Sleman, Yogykarta”. Skripsi mahasiswa Fakultas Peternakan, Universitas Gadjah Mada, Yogyakarta diakses dari http://etd.repository.ugm.ac.id/index.php?mod=penelitian_detail\&sub=Penelitia nDetail\&act=view\&typ=html\&buku_id=74500\&obyek_id=4 pada tanggal 27 Februari 2018 pukul 14.20

Ariyanti, F. (2014). "Performans Induk dan Pertumbuhan Prasapih Sapi Peranakan Ongole dan Silangan Simental-Peranakan Ongole di Kelompok Village Breeding Center di Daerah Istimewa Yogyakarta". Tesis mahasiswa Fakultas Peternakan. Universitas Gadjah Mada, Yogyakarta. Diakses dari:http://etd.repository.ugm.ac.id/index.php?mod=penelitian_detail\&sub=Pene litianDetail\&act=view \&typ=html\&buku_id=69061\&obyek_id=4 pada tanggal 27 Februari 2018 pukul 14.16

Berardinelli, J. G., \& P. S. Joshi. (2005). Introduction of Bulls at Different Days Postpartum on Resumption of Ovarian Cycling Activity in Primiparous Beef Cows. Journal of Animal Science, 83: 2106-2110.

Burns, P D, \& J C Spitzer. (1992). Influence of Biostimulation on Reproduction in Postpartum Beef Cows1r2. Journal of Animal Science, 70: 358-62. 
Baliarti E. et al. (2017). Scan Abstract ICTA 2016 PDF.pdf. 1st ed. ed. nuringtyas T Isnansetyo A. Springer, Cham. https://link.springer.com/chapter/10.1007/978-3319-60363-6_37.

Fiol, C., G. Quintans, \& R. Ungerfeld. (2010). Response to Biostimulation in PeriPuberal Beef Heifers: Influence of Male-Female Proximity and Heifer's Initial Body Weight. Theriogenology, 74: 569-75.

Landaeta-Hernández, A. J. et al. (2006). Effect of Biostimulation on the Expression of Estrus in Postpartum Angus Cows. Theriogenology, 61: 1521-1532.

Miller, V., \& R. Ungerfeld. 2008. Weekly Bull Exchange Shortens Postpartum Anestrus in Suckled Beef Cows. Theriogenology, 69: 913-917.

Oliveira, C. M.G. et al. (2009). Effects of Biostimulation and Nutritional Supplementation on Pubertal Age and Pregnancy Rates of Nelore Heifers (Bos Indicus) in a Tropical Environment. Animal Reproduction Science, 113: 38-49.

Pradana, A.B.K. (2014). "Pengaruh umur Induk Sapi Peranakan Onggole dan Simental Peranakan Ongole Terhadap Post Partum Estrus di Kelompok Ternak di Kecamatan Sayegan, Sleman, Yogykarta". Skripsi mahasiswa Fakultas Peternakan, Universitas Gadjah Mada, Yogyakarta. Diakses dari:http://etd.repository.ugm.ac.id/index.php?mod=penelitian_detail\&sub=Peneli tianDetail\&act=view\&typ=html\&buku_id=74515\&obyek_id=4

Rekwot, P. I., D. Ogwu, E. O. Oyedipe, \& V. O. Sekoni. (2001). The Role of Pheromones and Biostimulation in Animal Reproduction. Animal Reproduction Science, 65: 157170.

Thalib, A et al. (2000). Pengaruh Perlakuan Silase Jerami Padi Dengan Mikroba Rumen Kerbau Terhadap Daya Cerna Dan Ekosisitem Rumen Sapi. JITV, 5: 276-81. 